\title{
Pemanfaatan Data Angin untuk Karakteristik Gelombang Laut di Perairan Natuna Berdasarkan Data Angin Tahun 2009 - 2018
}

\author{
Ary Afriady $^{1 *}$, Tasdik Mustika Alam ${ }^{1}$, Mochamad Furqon Azis Ismail ${ }^{2}$ \\ ${ }^{1}$ Sekolah Staf dan Komando Angkatan Laut \\ Jl. Cileduk Raya, Cipulir, Kebayoran Lama, Jakarta 12230 \\ ${ }^{2}$ Pusat Penelitian Oseanografi, Lembaga Ilmu Pengetahuan Indonesia \\ Jl. Pasir Putih 1, Ancol Timur, Jakarta 14430 \\ Email: ary_afriady@tnial.mil.id
}

\begin{abstract}
Abstrak
Analisis data angin dilakukan untuk meramalkan dan menentukan karakteristik gelombang laut di perairan Pulau Natuna. Data angin yang digunakan dalam penelitian ini berasal dari National Centers for Environmental Prediction(NCEP) selama 10 tahun dari tahun 2009 sampai dengan tahun 2018. Metoda yang digunakan untuk estimasi tinggi, periode dan arah gelombang laut yang dibangkitkan oleh angin adalah metode Svedrup, Munk dan Bretschneider (SMB).Hasil perhitungan peramalan karakteristik gelombang diperoleh bahwa pembentukan gelombang didominasi oleh arah yang berasal dari timur laut dan terjadi pada musim barat dan musim peralihan 1.Adapun pada musim timur dan peralihan, arah dominan gelombang masing-masing berasal dari selatan dan barat daya. Tinggi gelombang maksimum 1,0-1,4 m sering terjadi pada musim musim timur, adapun tinggi gelombang minimum 0,2-0,6 $\mathrm{m}$ dominan terjadi pada musim musim peralihan. Periode gelombang dominan ditemukan pada kisaran 7-9 detik yang terjadi pada tiap musim.
\end{abstract}

Kata kunci : angin, gelombang laut, Pulau Natuna, monsun

\section{Abstract \\ The Utilization of Wind Data to Determine the Ocean Waves in Natuna Island Waters}

The analysis of wind data has been done to forecast and determine the characteristic of the ocean wave in Natuna Island waters. The wind data in this study was obtained from the National Centers for Environmental Prediction (NCEP) for a period of 10 years from 2009 to 2018. The method to estimate wave height, wave period, and wave direction generated by wind is Sverdrup, Munk dan Bretschneider (SMB) system. The results of wave forecasting analysis show that the formation of the wave is mainly originated from the northeast which occurs during the west and first transition season. As for the east and second transition season, the origin of wave formation coming from the south and southwest, respectively. The maximum wave height of 1.0-1.4 $\mathrm{m}$ frequently occurs during the east monsoon, while the minimum wave height. The dominant wave period is found in the range of 7-9 seconds, which occurs in every season.

Keywords: winds, ocean waves, Natuna Island, monsoon

\section{PENDAHULUAN}

Kepulauan Natuna terletak di ujung barat daya Laut Cina Selatan dan berada di antara Semenanjung Malaysia dan Pulau Kalimantan (Gambar 1). Perairan di sekitar Kepulauan Natuna merupakan bagian dari Sea Lane of Communication (SLOC) yang menghubungkan kawasan Asia Timur dan Samudera Hindia dan sebaliknya. Perairan Pulau Natuna berada pada posisi 101.6'- 70,19' Lintang Utara dan 105.0 00'-110,000' Bujur Timur, dengan batas-batas sebagai berikut: Utara berbatasan dengan Vietnam dan Kamboja, Selatan berbatasan dengan Kabupaten Kepulauan Riau, Timur berbatasan dengan Malaysia Timur dan Kalimantan Barat, dan Barat berbatasan dengan Semenanjung Malaysia dan Pulau Bintan (Kabupaten Kepulauan Riau).

Kepulauan Natuna dan perairan sekitarnya termasuk ke dalam Propinsi Kepulauan Riau dan merupakan jajaran pulau-pulau terluar serta garda terdepan dari penjaga kedaulatan NKRI. Oleh sebab itu, pembangunan di Pulau Natuna merupakan prioritas yang bersifat strategis untuk 
mengamankan kepentingan nasional Indonesia. Pengetahuan karakteristik Gelombang laut seperti tinggi, periode dan arah gelombang merupakan salah satu parameter oseanografi fisik yang sangat penting untuk perencanaan, pelayaran laut (Kurniawan dan Khotimah, 2015), pengembangan dan pembangunan infrastruktur di laut seperti pelabuhan, perlindungan bentuk pantai (Hadi dan Sugianto, 2012), dan tanggul penahan gelombang (De Deo, 2007; Rabung 2014). Hasil dari penelitian ini diharapkan dapat menghasilkan informasi awal yang bisa dimanfaatkan untuk kajian pembangunan dan pengembangan pelabuhan laut Natuna (Anggara et al., 2018), pengembangan kawasan konservasi laut daerah, dan budidaya perikanan laut (Sagala et al., 2014).

\section{MATERI DAN METODE}

Peramalan karakteristik gelombang laut di perairan Pulau Natuna dilakukan dengan menggunakan data angin selama 10 tahun dari tahun 2009 sampai tahun 2018 yang berasal dari National Centers for Environmental Prediction NCEP (Kalnay et al., 1996). Data angin dalam bentuk komponen angin zonal dan meridonal tersebut dapat di unduh di: https://www.esrl.noaa.gov/psd/data/gridded/data.n cep.html. Data angin kemudian dikonversi menjadi data magnitude kecepatan dan arah angin.

Klasifikasi kecepatan angin dilakukan untuk menghitung frekuensi kejadian kecepatan angin maksimum. Adapun arah angin diklasifikasikan menjadi delapan penjuru mata angin yaitu barat, barat laut, barat daya, utara, tenggara, selatan, timur, timur laut, dan tenggara. Berdasarkan hasil klasifikasi kecepatan angin maksimum dan arah angin, maka distribusi frekuensi dari setiap kecepatan dan arah angin dapat dihitung serta digambarkan dalam bentuk mawar angin (windrose).

Teknik peramalan dan penentuan karakteristik gelombang laut dari data angin ini dikenal dengan metode Svedrup, Munk dan Bretschneider (SMB) dari CERC (1984). Prinsip dasar metode SMB adalah memprediksi tinggi, periode dan arah gelombang yang dihitung dari data arah, kecepatan, dan durasi angin. Metode ini sangat tergantung kepada panjang wilayah dari pembangkitan gelombang laut oleh angin yang dibatasi oleh pulau yang merintanginya yang disebut sebagai fetch (Umpel et al., 2015). Panjang fetch ditentukan dengan membangun garis-garis secara radial yang ditarik dari area studi sampai memotong garis pantai seperti yang terlihat pada Gambar 1. Adapun panjang fetch efektif dihitung berdasarkan formula:

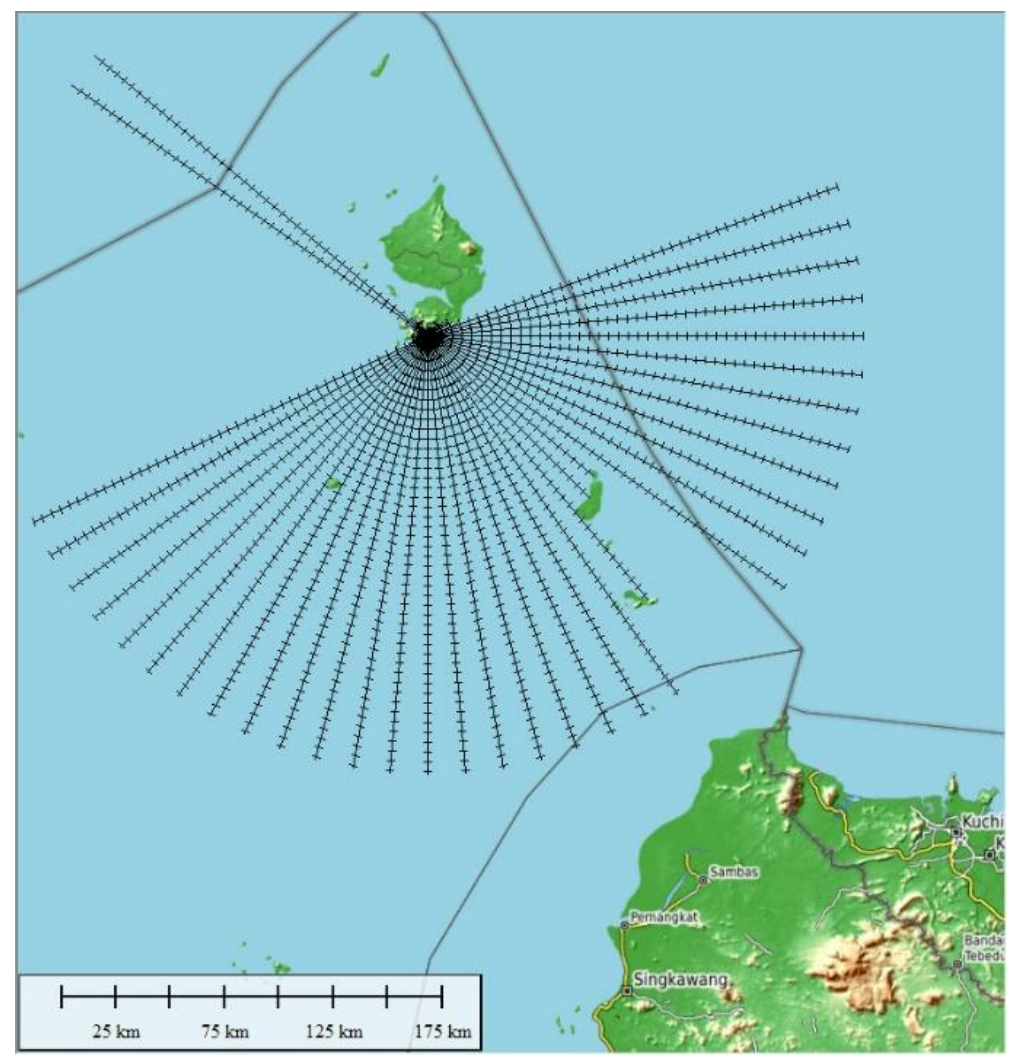

Gambar 1. Lokasi penelitian di perairan Pulau Natuna. Garis hitam bergerigi merupakan panjang wilayah pembangkitan gelombang laut oleh angin. 


$$
\mathrm{F}_{\mathrm{ef}}=\frac{\sum \mathrm{F}_{1} \cos ^{2}(\alpha)}{\sum \cos \alpha_{1}}
$$

Dimana $F_{\text {ef }}=$ panjang $F$ efektif; $F_{i}=$ panjang fecth pada arah ke-i (CERC, 1984).

\section{HASIL DAN PEMBAHASAN Karakteristik angin}

Pola angin dilokasi penelitian dapat dibagi menjadi empat pola berdasarkan musim yang ada yaitu: musim barat, musim peralihan 1, musim timur, dan musim peralihan 2. Hasil pengolahan klasifikasi data angin dominan dan mawar angin dari tahun 2009-2018 diperairan Pulau Natuna dapat dilihat pada Tabel 1 dan Gambar 2. Secara umum, perairan Pulau Natuna dikontrol oleh sistem angin monsun yang berubah dominasi arahnya sesuai dengan musim (Wyrtki, 1961; Anggara et al., 2018, Muliati et al., 2019).

Dari Gambar 2a, terlihat bahwa pada musim barat yaitu bulan Desember, Januari dan Februari, arah angin bertiup dominan dari arah utara dengan persentase tingkat kejadian 52,08\%, timur laut dengan persentase tingkat kejadian $24,82 \%$, dan barat laut persentase tingkat kejadian $5,13 \%$. Kecepatan dominan urutan tiga besar berapa pada kisaran 3-5 $\mathrm{m} /$ detik dengan persentase tingkat kejadian $22,46 \%, 5-7 \mathrm{~m} /$ detik dengan persentase tingkat kejadian $32,26 \%$, dan 7-9 $\mathrm{m} /$ detik dengan persentase tingkat kejadian 18,69\%. Penelitian karakteristik gelombang yang dilakukan oleh Wicaksana et al. (2015) di Selat Karimata juga menunjukan bahwa pada musim barat mencapai puncaknya pada musim barat. Hal ini dikarenakan adanya sirkulasi angin monsoon yang datang dari daerah bertekanan tinggi di daerah subtropis lintang utara menuju daerah bertekanan rendah di lintang selatan subtropis (Chang et al., 2005; Tjasyono, 2004).

Gambar 2b menunjukan mawar angin pada musim peralihan 1 yaitu pada bulan Maret, April dan Mei. Pada musim peralihan 1 arah angin didominasi oleh angin dari Timur laut dengan persentase tingkat kejadian $31,24 \%$, Utara dengan persentase tingkat kejadian 15,20\%) dan Tenggara sebesar $6,88 \%$. Kecepatan angin dominan urutan tiga besar berada pada kisaran 1-3 m/detik dengan persentase tingkat kejadian 11,46\%, 3-5 m/detik dengan persentase tingkat kejadian $31,10 \%$, dan 5-7 m/detik dengan persentase tingkat kejadian $23,67 \%$. Pergerakan matahari dari garis balik lintang selatan (tropic of Capricorn) menuju garis balik lintang utara (tropic of Cancer) menyebabkan adanya transisi perubahan kecepatan dan arah angin (Tjasyono, 2004).
Adanya perubahan sirkulasi angin monsoon dari musim barat dan peralihan 1 terlihat pada musim timur (Juni, Juli, Agustus) dimana terjadi pembalikan arah angin seperti yang terlihat Gambar 2c . Arah angin didominasi oleh angin yang berasal dari selatan dengan persentase tingkat kejadian $22,43 \%$, barat daya dengan persentase tingkat kejadian $20,40 \%$ dan tenggara dengan persentase tingkat kejadian $10,19 \%$. Kecepatan angin dominan urutan tiga besar berada pada kisaran 1-3 $\mathrm{m} /$ detik dengan persentase tingkat kejadian 14,98\%, 3-5 m/detik dengan persentase tingkat kejadian $29,76 \%$, dan 5-7 $\mathrm{m} /$ detik sebesar $18,25 \%$. Pengaruh dari pergerakan matahari dari garis balik lintang utara (tropic of Cancer) menuju garis balik lintang selatan (tropic of Capricorn) yang terjadi pada bulan September, Oktober dan November (Tjasyono, 2004) menyebabkan adanya transisi perubahan arah mata angin seperti yang terlihat pada Gambar 2d. Mawar angin pada musim peralihan 2 pada bulan September, Oktober dan November. Di wilayah perairan Pulau Natuna pada musim peralihan 2 menunjukan bahwa arah angin didominasi oleh angin dari barat daya dengan persentase tingkat kejadian 16,76\%, timur laut dengan persentase tingkat kejadian 12,13\%, dan selatan dengan persentase tingkat kejadian $11,48 \%$. Kecepatan angin yang dominan berada pada kisaran 1-3 $\mathrm{m} /$ detik dengan persentase tingkat kejadian 17,50\%, 3-5 m/detik dengan persentase tingkat kejadian $30,58 \%$, dan 5-7 $\mathrm{m} /$ detik dengan persentase tingkat kejadian $14,43 \%$. Pergerakan matahari dari garis balik lintang lintang utara (tropic of Cancer) menuju garis balik selatan (tropic of Capricorn) menyebabkan adanya transisi arah angina dari musim timur ke musim barat (Tjasyono, 2004).

\section{Karakteristik gelombang laut}

Hasil perhitungan tinggi, periode dan arah gelombang laut tiap musim yang disusun berdasarkan frekunesi kejadiannya terhadap 8 arah mata angin disajikan di Tabel 2, adapun profil mawar gelombang (waverose) disajikan di Gambar 3. Secara umum karakteristik gelombang di perairan Pulau Natuna dapat dibagi menjadi empat pola berdasarkan musim yang ada yaitu musim barat, musim peralihan 1, musim timur danmusim peralihan 2. Hasil dari penelitian ini melengkapi penelitian mengenai karakteristik gelombang laut yang sebelumnya dilakukan oleh Anggara et al. (2019) dan Muliati et al. (2018).

Berdasarkan Tabel 2, menunjukan bahwa pada musim barat tinggi gelombang dominan tiga 
Tabel 1. Kecepatan dan arah angin dominan rata-rata tiap musim dari tahun 2009-2018

\begin{tabular}{lcccc}
\hline \multirow{2}{*}{ Bulan } & \multicolumn{2}{c}{ Angin Dominan } & \multicolumn{2}{c}{ Arah Dominan } \\
\cline { 2 - 5 } & Kec $(\mathrm{m} / \mathrm{det})$ & Persentase $(\%)$ & Arah (derajat) & Persentase $(\%)$ \\
\hline \multirow{2}{*}{ Musim Barat } & $3-5$ & 22,46 & Utara & 52,08 \\
& $5-7$ & 36,26 & Timur Laut & 24,82 \\
\multirow{3}{*}{ Musim Peralihan 1 } & $7-9$ & 18,69 & Barat Laut & 5,13 \\
& $1-3$ & 11,46 & Timur Laut & 31,24 \\
Musim Timur & $3-5$ & 31,10 & Utara & 15,20 \\
& $5-7$ & 23,67 & Tenggara & 6,88 \\
Musim Peralihan 2 & $1-3$ & 14,98 & Selatan & 22,43 \\
& $3-5$ & 29,76 & Barat Daya & 20,40 \\
& $5-7$ & 18,25 & Tenggara & 10,19 \\
& $1-3$ & 17,50 & Barat Daya & 16.76 \\
& $3-5$ & 30,58 & Timur Laut & 12.13 \\
\end{tabular}
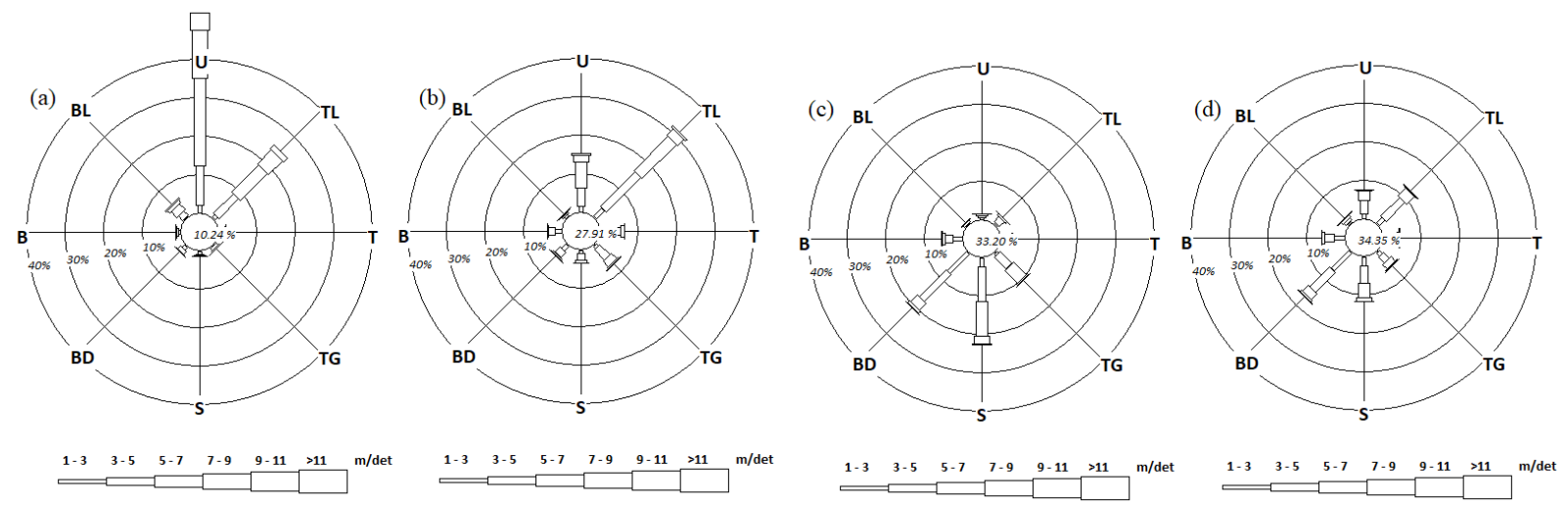

Gambar 2. Profil mawar angin (windrose) diperairan Pulau Natuna pada musim: (a) barat; (b) peralihan 1; (c) timur; (d) peralihan 2.

terbesar yaitu antara 0,2-0,6 m, 0,6-1,0 m dan 1,0$1,4 \mathrm{~m}$, dengan persentase tingkat kejadian masingmasing sebesar $10,02 \%, 12,68 \%, 6,29 \%$. Periode gelombang dominan berada pada kisaran 3-5 detik, 5-7 detik dan 7-9 detik, dengan persentase tingkat kejadian masing-masing sebesar $1,31 \%$, $18,55 \%, 10,52 \%$. Hasil mawar gelombang yang disajikan pada Gambar 3a menunjukan bahwa arah gelombang didominasi oleh arah yang datang dari timur laut dengan persentase tingkat kejadian $24,77 \%$, disusul dengan arah yang datang dari barat daya dengan persentase tingkat kejadian $2,14 \%$ dan gelombang yang datang dari selatan dengan persentase tingkat kejadian $1,28 \%$.

Pada Musim peralihan 1 terjadi sedikit perubahan arah dominan datang gelombang seperti yang terlihat pada Gambar 3b. Hal ini terjadi karena adanya perubahan arah angin sebagai pembangkit gelombang dari musim barat ke musim timur. Dominasi arah gelombang berasal dari timur laut dengan persentase tingkat kejadian $31,05 \%$, tenggara dengan persentase tingkat kejadian
$6,88 \%$, dan timur dengan persentase tingkat kejadian $6,22 \%$. Tinggi dan periode gelombang dominan pada musim peralihan 1 terjadi peningkatan persentase tingkat kejadian jika dibandingkan dengan musim sebelumnya. Tinggi gelombang dominan pada kisaran 0,2-0,6 m, 0,6$1,0 \mathrm{~m}$ dan 1,0-1,4 $\mathrm{m}$ dengan persentase tingkat kejadian masing-masing sebesar 19,86\%, 20,94\%, $8,44 \%$. Periode gelombang dominan kisaran 5-7 detik menunjukan persentase tingkat kejadian $28,47 \%$, lebih tinggi dari periode gelombang kisaran 7-9 detik dan 9-11 detik dengan frekuensi tingkat kejadian $15,85 \%$ dan 3,91\%.

Hasil peramalan arah dominan gelombang laut pada musim timur dapat dilihat pada Gambar 3c. Pada musim timur arah datang gelombang didominasi oleh arah dari selatan dengan persentase sebesar $22,40 \%$, barat daya dengan persentase sebesar $20,16 \%$, dan tenggara dengan persentase sebesar 10,19\%. Rentang tinggi gelombang dominan berada pada kisaran 0,2-0,6 $\mathrm{m}$ dengan persentase sebesar $13,10 \%, 0,6-1,0$ 
Tabel 2. Tinggi, periode, dan arah gelombang dominan tiap musim dari tahun 2009-2018 di perairan Pulau Natuna

\begin{tabular}{ccccccc}
\hline \multirow{2}{*}{ Bulan } & \multicolumn{2}{c}{ Tinggi } & \multicolumn{2}{c}{ Periode } & \multicolumn{2}{c}{ Arah } \\
\cline { 2 - 6 } & Tinggi $(\mathrm{m})$ & $\%$ & Periode (det) & $\%$ & Arah & $\%$ \\
\hline \multirow{3}{*}{ Musim Barat } & $0,2-0,6$ & 10,02 & $3-5$ & 1,31 & Timur laut & 24,77 \\
& $0,6-1,0$ & 12,68 & $5-7$ & 18,55 & Barat Daya & 2,14 \\
Musim & $1,0-1,4$ & 6,29 & $7-9$ & 10,52 & Selatan & 1,28 \\
Peralihan 1 & $0,2-0,6$ & 19,86 & $5-7$ & 28,47 & Timur laut & 31,05 \\
& $0,6-1,0$ & 20,94 & $7-9$ & 15,85 & Tenggara & 6,88 \\
Musim Timur & $1,0-1,4$ & 8,44 & $9-11$ & 3,91 & Timur & 6,22 \\
& $0,2-0,6$ & 13,10 & $5-7$ & 10,48 & Selatan & 22,40 \\
Musim & $0,6-1,0$ & 17,62 & $7-9$ & 27,10 & Barat Daya & 20,16 \\
Peralihan 2 & $0,2-0,6$ & 17,32 & $9-11$ & 17,64 & Tenggara & 10,19 \\
& $0,6-1,0$ & 19,38 & $5-7$ & 17,78 & Barat Daya & 16,45 \\
& $1,0-1,4$ & 15,99 & $7-9$ & 19,78 & Timur laut & 12,01 \\
\end{tabular}

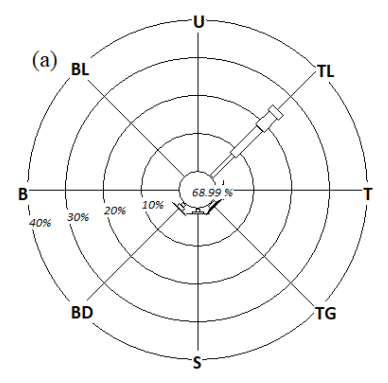

$0.20 .6 \quad 0.6-1.0 \quad 1.0-1.4 \quad 1.4-1.8$ 1.8-2.2. $>2.2$ (Meter)

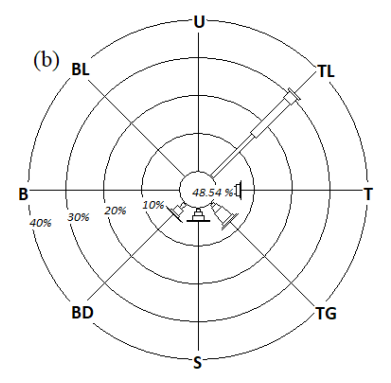

$0.2-0.6$ 0.6-1.0 1.0-1.4 1.4-1.8 1.8-2.2. $>2.2$ (Meter)

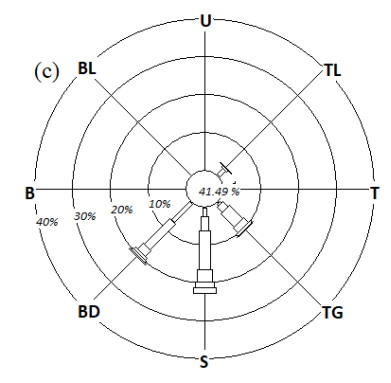

0.2-0.5 0.6-1.0 1.0-1.4 1.4-1.18 1.8-2.2. $>2.2$ (Meter)

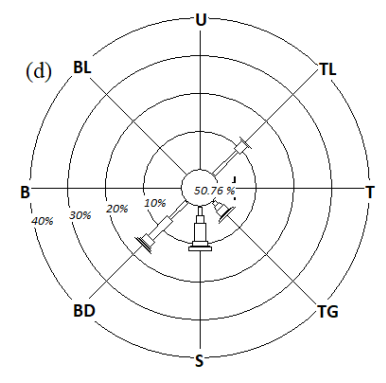

$0.2-0.6 \quad 0.6-1.0 \quad 1.0-1.4 \quad 1.4-1.8$ 1.8-2.2.2 $>2.2$ (Meter)

Gambar 3. Profil mawar gelombang (waverose) diperairan Pulau Natuna pada musim: (a) barat; (b) peralihan 1; (c) timur; (d) peralihan 2.

mdengan persentase sebesar $17,62 \%$, dan $1,0-1,4$ $\mathrm{m}$ dengan persetase sebesear $17,32 \%$. Periode gelombang dominan berada pada kisaran 5-7 detik, 7-0 detik, dan 9-11 detik dengan persentasi kejadian masing-masing sebesar $17,78 \%$, $19,78 \%$, dan $8,23 \%$.

Musim peralihan 2 didominasi oleh arah gelombang yang datang dari barat daya, timur laut dan selatan (Gambar 3d), dengan masing-masing persentasi tingkat kejadian $16,45 \%, 12,01 \%$, dan $11,41 \%$. Tinggi gelombang dominan antara $0,2-$ $0,6 \mathrm{~m}$ dengan persentase $19,38 \%, 0,6-1,0 \mathrm{~m}$ dengan persentase $15,99 \%$, dan 1,0-1,4 m dengan persentase $9,02 \%$. Periode dominan datangnya gelombang dengan kisaran 5-7 detik memiliki persentase $17,78 \%$, kisaran 7-9 detik dengan persentasi $19,78 \%$ dan 9-11 detik terjadi sebanyak $8,23 \%$. Secara umum, dominasi gelombang dengan kisaran tinggi $0,2-0,6 \mathrm{~m}$ terjadi pada musim transisi antar monsun, sedangkan gelombang dengan kisaran 1,0-1,4 m terjadi pada musim timur.

\section{KESIMPULAN}

Berdasarkan analisis data angin dari tahun 2009-2018, didapatkan bahwa karakteristik angin di perairan Pulau Natuna bervariasi terhadap musim yang didominasi oleh angin monsun. Musim barat dan musim peralihan 1 didominasi oleh angin yang datang dari arah utara dan timur laut, dengan masing-masing persentase kecepatan dominan pada kisaran 5-7 m/detik dan 3-5 $\mathrm{m} /$ detik. Pada musim timur dan peralihan 2 didominasi oleh angin yang berasal dari selatan dan barat daya dengan persentase kecepatan dominan pada kisaran 3-5 m/detik. Hasil peramalan gelombang laut musiman diperairan Pulau Natuna dengan menggunakan metode SMB, diketahui bahwa pembentukan gelombang yang dilokasi penelitian dominasi oleh arah yang berasal dari timur laut yang terjadi pada musim barat dan musim peralihan 1. Adapun pada musim timur dan peralihan, arah dominan gelombang masing-masing berasal dari selatan dan barat daya. Tinggi gelombang maksimum 1,0-1,4 m 
sering terjadi pada musim musim timur, adapun tinggi gelombang minimum 0,2-0,6 $\mathrm{m}$ dominan terjadi pada musim musim peralihan. Periode gelombang dominan ditemukan pada kisaran 7-9 detik yang terjadi pada tiap musim.

\section{DAFTAR PUSTAKA}

Anggara, P.D., Alam, T.M., Adrianto, D. \& Pranowo, W.S. 2018. The Wave Characteristics in Natuna Sea and Its Adjacent for Naval Operation Base Purposes. IOP Conf. Series: Earth and Environmental Science, 176.

CERC (Coastal Engineering Research Centre)., 1984. Shore Protection Manual. Vicksburg, Mississippi: U.S. Army Corps of Engineers (Vol. 1).

Chang, C.P., Wang, Z., Mcbride, J. \& Liu, C. 2005 Annual Cycle of Southeast AsiaMaritime Continent Rainfall and the Asymmetric Monsoon Transition. Journal of Climate, 18:287-301.

De Deo, P.J. 2007. Peranan Survei Hidrografi Untuk Perencanaan Lokasi Pembangunan Pelabuhan. Jurnal Spectra, 5(10):1-19.

Hadi, S. \& Sugianto, D.N. 2012. Model Distribusi Kecepatan Angin untuk Peramalan Gelombang dengan Menggunakan Metode Darbyshire dan SMB di Perairan Semarang. Buletin Oseanografi Marina, 1(3):25-32.

Kalnay, E., Kanamitsu, M., Kistler, R., Collins, W., Deaven, D., Gandin, L., Iredell, M., Saha, S., White, G., Woollen, J. \& Zhu, Y., 1996. The NCEP/NCAR 40-year reanalysis project. Bulletin of the American meteorological Society, 77(3):437-472.
Kurniawan, K. \& Khotimah, M.K. 2015. Ocean Wave Characteristics in Indonesian Waters for Sea Transportation Safety and Planning. The Journal for Technology and Science, 26(1):19-27.

Muliati, Y., Tawekal, R.L., Wurjanto A., Kelvin, J. \& Pranowo, W.S. 2019. Wind Wave Modeling in Natuna Sea: a Comparison Among SWAN, SEAFINE, and ERAINTERIM. International Journal of Geomate 16(54):176-184

Rabung, F. 2014. Prediksi Gelombang Signifikan Sekitar Pantai Makassar untuk Perencanaan Pembangungan Infrastruktur Pantai. Prosiding Hasil Penelitian Teknologi Terapan Volume 8.

Sagala, S.L., Bramawanto, R., Kuswardani, A.R.T.D. \& Pranowo, WS. 2014. Distribusi Logam Berat Di Perairan Natuna. Jurnal Ilmu dan Teknologi Kelautan Tropis, 6(2):297-310.

Tjasyono, B., 2004. Klimatologi. Penerbit ITB. Bandung.

Umpel, F.I., Mamoto, J.D. \& Jasin, M.I. 2015. Studi Karakteristik Gelombang Pada Dearah Pantai Matani Satu. Jurnal Sipil Statik. 3(9):651-661

Wicaksana S., Sofin, I., Pranowo, W., Kuswardani, A.R.T.D., Saroso \& Sukoco, N.B. 2015. Karakteristik Gelombang Signifikan di Selat Karimata dan Laut Jawa Berdasarkan Rerata Angin 9 Tahunan (20052013). OmniAkuatika 11(2):33-40.

Wyrtki., 1961. Physical Oceanography of the Southeast Asian Waters. Naga Report Vol 2. University of California, California. 